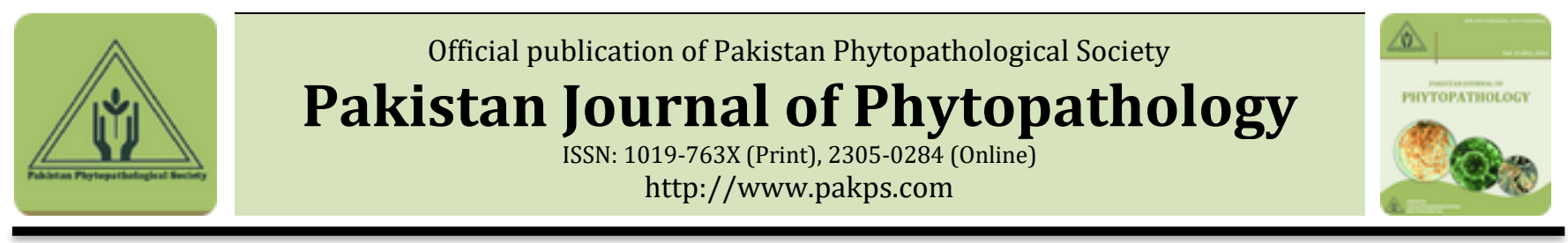

\title{
EFFECT OF SEED DRESSING CHEMICALS ON EMERGENCE, YIELD AND AGAINST SOIL \& SEED BORN DISEASES OF WHEAT
}

\author{
aMuhammad Shahbaz*, bMuhammad Riaz, cSajjad Ali, bFaqir Ahmad, dAftab Hussain, eGhulam Nabi, \\ fMuhammad T. Chaudhry, gSher Muhammad \\ a Adaptive Research Farm Sheikupura, Punjab, Pakistan. \\ ${ }^{b}$ Pest Warning and Quality Control of Pesticides, Sheikhupura, Punjab, Pakistan. \\ cPest Warning and Quality Control of Pesticides, Pattoki, Kasur, Punjab, Pakistan. \\ ${ }^{d}$ Agriculture Extension Pattoki, Kasur, Punjab, Pakistan. \\ eVegetable Research Sub Station Sheikhupura Punjab, Pakistan. \\ fDirector of Agriculture (Farms, Training \& Adaptive Research) Sheikhupura, Punjab, Pakistan. \\ ${ }^{g}$ Department of Bioinformatics and Biotechnology, Govt. College University, Faisalabad, Pakistan.
}

\section{A B S T R A C T}

Field studies were carried out at Adaptive Research Farm, Sheikhupura Punjab, Pakistan having rice- wheat cropping system to evaluate the efficacy of three different fungicides against seed or soil borne wheat diseases (Root rot, Loose smut \& Black Point disease) during two successive seasons 2015-16 \& 2016-17.The fungicides were Thiophenate methyl, compound fungicides i.e. Tubeconzol+ imidachloprid and Difenoconazol + cypnoconazol used as seed treatment @ $2.5 \mathrm{~g}, 4.0 \mathrm{ml} \& 1.0 \mathrm{ml}$ per kilogram of seed respectively. Incidence of root rot, loose smut \& black point disease was recorded by selecting 15 plants, 100 plants \& 100 seeds randomly of each treatment from each plot respectively in comparison with untreated control. All the fungicides significantly increased the seedling emergence per square meter about 15 percent as compared to untreated plot. Tubeconzol+ imidachloprid and Difenoconasol +cypnoconazol were the most effective seed dressing fungicide and reduced the number of rotted roots, loose smut infected spikes and black point infested seeds. Maximum number of productive tillers per square meter, healthy grains per spike and yield kg per hectare were recorded with compound fungicide Tubeconzol+ Imidachloprid followed by Difenoconazol + Cypnoconazol treated plots as compared to untreated plot.

Keywords: Wheat, seed treatment, germination, yield, yield components

\section{INTRODUCTION}

Wheat (Triticum aestivum L.) is considered as staple food by two third of the world population and the most important cereal crop (Majumder, 1991). It is the key crop of Pakistan because it is used as the main source of human food and the straw is also used for industrial product as well as feed for livestock. It meets the major nutritional requirements and gaining popularity all over the world and especially in Pakistan because a

Submitted: October 14, 2018

Revised: October 24, 2018

Accepted for Publication: November 22, 2018

* Corresponding Author:

Email: shahbazssms2014@gmail.com

(C) 2017 Pak. J. Phytopathol. All rights reserved. staple food. In Pakistan about 25492 thousand ton wheat is produced from an area about 8950 thousand hectare While in the Punjab province the area under wheat crop was 6917 thousand hectare and its production remained 19526.67 thousand ton during 2016-17 (Anonymous, 2017).

Wheat plants are exposed to many harms and stresses that creates hindrance in the growth and development at all stages. According to statement of (Razzaque and Hossain, 1991), different seed borne fungi such as Bipolaris sorokiniana, Alternaria alternata, Curvularia lunata, Fusurium spp. cause $20 \%$ yield losses in wheat. Seed is the main source for the transmission of plant pathogens that cause diseases in plant. The seed borne pathogens are associated externally or internally with 
seed as contaminant. Seed borne pathogens affect the seed in number of ways like seed abortion, seedling blight/wilting, necrosis, or reduce the germination as well as seedling emergence by systemic or local infection resulting in the development of disease at later stages of plant growth. Black point disease affects the vigour and luster of wheat grains that reduces the market value (Solanki et al., 2006). Black point disease caused by Bipolaris sorokiniana and Alternaria alternata, is an important seed-borne disease in many wheat growing countries of the world (Zishan et al., 2005; Hasabnis et al., 2006). Smiley et al., (2013) depicted that Fusarium spp. cause crown rot and often invade the emerging coleoptile and also reported that mostly wheat diseases are caused by fungi which attack seed, roots and foliage. Rekanović, et al., (2010) also stated that fungi are the major seed-borne pathogen as they render losses in a number of ways. It was stated by many authors that increased level of crop debris influence the incidence and severity of plant diseases. (Bailey \& Lazarovits, 2003; Paulitz, 2006; Matusinsky et al., 2009). Krupinsky et al., (2002) reported that in the upper layer of soil there are larger microbial populations that hinder plant growth.

Seed treatment is a process that alleviates externally or internally seed borne pathogens and resulting emergence of a healthy seedling subsequently a healthy plant. Treated seeds promote good seedling establishment, lessen yield loss and to avoid further spread of pathogens. The methods of treating seeds are designed for protecting plants rather than curing them after they become diseased. It was described by Bradley et al., 2001; Cook et al., 2002 that seed treatment with fungicide is used for disease management in grain crops as positive impact on early plant growth. Galperin et al., (2003) also reported that a protective zone is formed by fungicides around germinating seeds and reduce diseases that caused by seed /soil-borne pathogens. Fungicidal treatment is an option to reduce primary inoculum of seed and soilborne fungi (Ilyas et al., 1998)

Under Adaptive Research zone Sheikhupura, the seedling blight, wilting at early stage of wheat crop and wheat grains were found completely or partially discloured and shriveled, it was observed at farm as well as at farmers field. Keeping in view the yield losses and problem faced by farming community of rice-wheat cropping system, a study was planned to test different fungicides as seed treatment before sowing of wheat crop. The protectants chemicals vary from crop to crop and area to area so this experiment will be supportive for the farmers in local climatic conditions, in reduction the losses in yield and improve the quality of seed.

\section{MATERIAL AND METHODS}

Studies were carried out during the two consecutive seasons 2015-16 \& 2016-17 at Adaptive Research Farm, Sheikhupura. The experiment was comprised of four treatments and deliberated in Randomized Complete Block Design (RCBD) with three repeats for each treatment. The treatments were three different fungicides viz: Thiophenate methyl (Topsin-M), Tubeconzol+ Imidachloprid (Hombare) and Difenoconazol + Cypnoconazol (Dividend Star) @ $2.5 \mathrm{gm}$, $4 \mathrm{ml} \& 1 \mathrm{ml}$ per $\mathrm{kg}$ of seed respectively and untreated control were compared to check the effect of seed dressing chemicals on plant emergence, incidence of diseases (root rot, loose smut \& black point), yield parameters and grain yield under the ecological zone of Sheikhupura , Punjab , Pakistan. During the both crop season, the plot size $26 \times 34$ sq feet was maintained and wheat seeds of variety Galaxy-2013 were treated separately with each fungicide before sowing. Seeds were treated with the help of rotary drum and then dried seeds were sown by using hand drill. All agronomic practices like fertilizer application, weed control and other practices remained constant in all the treatments during both the year.

\section{Data on the following parameters were noted during two consecutive crop periods:}

- Plant emergence per square meter area from each plot (by square frame), number of rotted roots symptoms per15 plants that randomly collected from each plot after 18 days of sowing

- Number of spikes infected with loose smut were estimated by randomly selected 100 plants of each treatment from each plot

- Number of grains infected with black point disease for this 100 seeds were collected after harvesting and threshing and note the symptoms of black point on grains and disease incidence percentage was calculated by:

$$
\text { Percent disease incidence }=\frac{\text { Number of plants infected with roots }}{\text { Total number of assessed plants }} \times 100 \%
$$


- Number of productive tillers in one square meter

- Plant height (average of 5 plants randomly collected from each plot).

- Healthy grains per panicle (average of 5 from each plot)

- Thousand grains weight (g)

- Grain yield Kg ha -1 were calculated at harvesting.

The parameters studied were exposed to analysis of variance and the means were compared by the least significant difference (LSD) at 0.05 probability level of significance. (Steel \& Torrie, 1980).

\section{RESULTS AND DISCUSSION}

Results presented in (Table 1) depict that during both the years, all the tried chemicals significantly increased

Table 1. Effect of seed dressing chemicals on emergence of wheat under field condition during two growing season.

\begin{tabular}{lcc}
\hline \multirow{2}{*}{ Treatments } & \multicolumn{2}{c}{ No. of wheat plants $\mathrm{m}^{-2}$} \\
\cline { 2 - 3 } & $2015-16$ & $2016-17$ \\
\hline $\mathrm{T}_{1}=$ Thiophenate Methyl & $188 \mathrm{~b}$ & $204 \mathrm{a}$ \\
\hline $\mathrm{T}_{2}=$ Tubeconazol + Imidachloprid & $196 \mathrm{a}$ & $208 \mathrm{a}$ \\
\hline $\mathrm{T}_{3}=$ Difenoconazol + Cypnoconazol & $194 \mathrm{ab}$ & $207 \mathrm{a}$ \\
\hline $\mathrm{T}_{4}=$ Control & $170 \mathrm{c}$ & $180 \mathrm{~b}$ \\
\hline LSD P $\leq .05$ & 7.27 & 9.28 \\
\hline
\end{tabular}

Means with different letters differ significantly at $\mathrm{P} \leq 0.05$

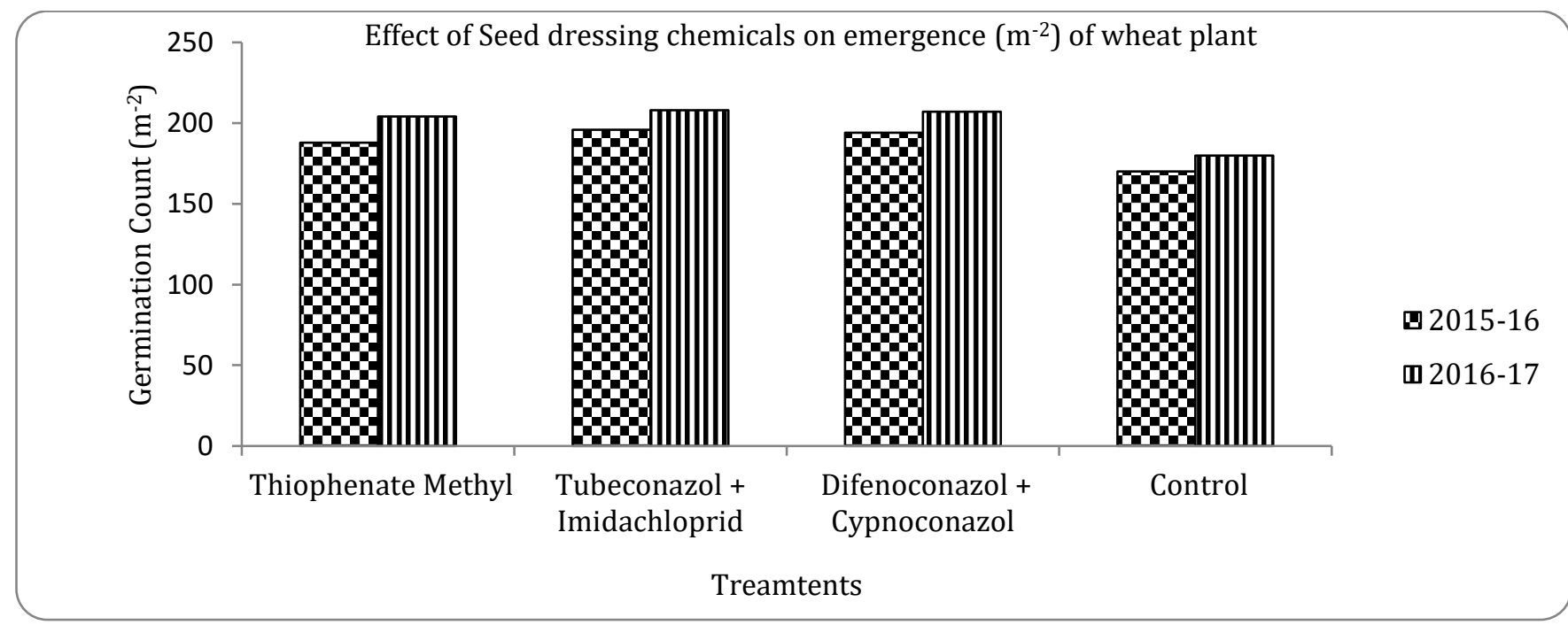

Treamtents

The findings of presented study is supported by Pikushova, (1995) indicated that Raxil (tebuconazole) used as wheat seed treatment controlled Alternaria and Fusarium and increased seed germination. El-Kholy, (1999) also indicated that fungicidal seed treatment of wheat increased at the rate of $15-20$ percent more number of healthy plants $\mathrm{m}^{-2}$ as compared to that of untreated one and tebuconazole was found the most effective fungicide. Sharma-Poudyal et al; (2005) the number of plants per square meter as compared with control. On the average of two seasons maximum 202 \& 196 healthy wheat plants were noted from the plots treated with Tubeconazol + Imidachloprid and Difenoconazol + Cypnoconazol respectively while third one fungicide (Thiophenate methyl) showed an intermediate effect as compared with the untreated plot from where 175 wheat plants were obtained. Munkvold \& O'Mara, (2002) stated that the effectiveness of seed dressing fungicides are usually evaluated by emergence percentage and used as an indication of plant vigor. Seed emergence and seedling growth has been widely accepted as main parameter to monitor growth responses it was reported by (Briggs and Dunn, 2000).

described that seed treatment increased the germination and reduced seedling infection. It was reported by Platz et al; (2001) that possible effects on emergence have been indicated by the triazole fungicides. The findings of above mentioned authors supported the results presented in this study, it also depicts that in the rice -wheat cropping system wheat seed treatment with compound fungicides enhance the emergence of wheat. 
Table.2. Influence of seed dressing fungicides on yield parameters during two growing seasons

\begin{tabular}{lllllllll}
\hline \multirow{2}{*}{ Treatments } & \multicolumn{2}{l}{ Plant height $(\mathrm{cm})$} & \multicolumn{2}{c}{ No. of fertile tillers $\mathrm{m}^{-2}$} & \multicolumn{2}{c}{ Grains/panicle } & \multicolumn{2}{c}{ 1000 grain weight $(\mathrm{g})$} \\
\cline { 2 - 9 } & $2015-16$ & $2016-17$ & $2015-16$ & $2016-17$ & $2015-16$ & $2016-17$ & $2015-16$ & $2016-17$ \\
\hline $\mathrm{T}_{1}$ & $94.17 \mathrm{bc}$ & $102.53 \mathrm{~b}$ & $237.33 \mathrm{c}$ & $275.00 \mathrm{c}$ & $31.33 \mathrm{~b}$ & $36.33 \mathrm{a}$ & $42.13 \mathrm{~b}$ & $38.11 \mathrm{c}$ \\
$\mathrm{T}_{2}$ & $100.80 \mathrm{a}$ & $106.00 \mathrm{a}$ & $251.33 \mathrm{a}$ & $297.67 \mathrm{a}$ & $36.00 \mathrm{a}$ & $38.66 \mathrm{a}$ & $45.38 \mathrm{a}$ & $41.25 \mathrm{a}$ \\
$\mathrm{T}_{3}$ & $96.07 \mathrm{~b}$ & $104.00 \mathrm{ab}$ & $245.33 \mathrm{~b}$ & $288.00 \mathrm{~b}$ & $32.66 \mathrm{ab}$ & $38.66 \mathrm{a}$ & $42.53 \mathrm{~b}$ & $39.81 \mathrm{~b}$ \\
$\mathrm{~T}_{4}$ & $91.67 \mathrm{c}$ & $98.10 \mathrm{~b}$ & $226.00 \mathrm{~d}$ & $243.00 \mathrm{~d}$ & $27.66 \mathrm{c}$ & $29.66 \mathrm{~b}$ & $42.20 \mathrm{~b}$ & $35.75 \mathrm{~d}$ \\
$\mathrm{LSD}$ & 4.39 & 3.20 & LSD 4.46 & 4.75 & 3.63 & 4.19 & 1.79 & 1.20 \\
$\mathrm{P} \leq 0.05$ & & &
\end{tabular}

Means having different letters vary significantly at $\mathrm{P} \leq 0.05$

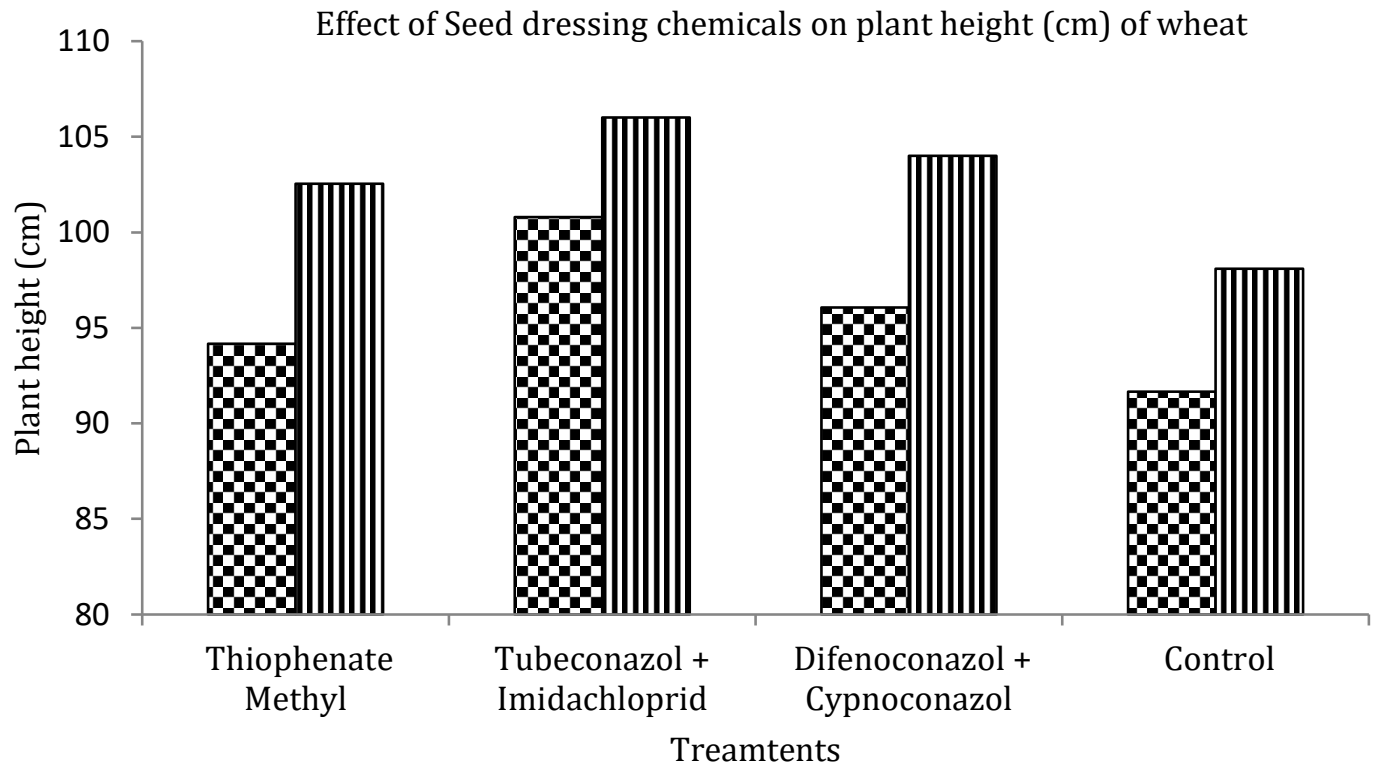

- 2015-16

( 2016-17

Effect of Seed dressing chemicals on fertile tillers $\left(\mathrm{m}^{-2}\right)$ of wheat

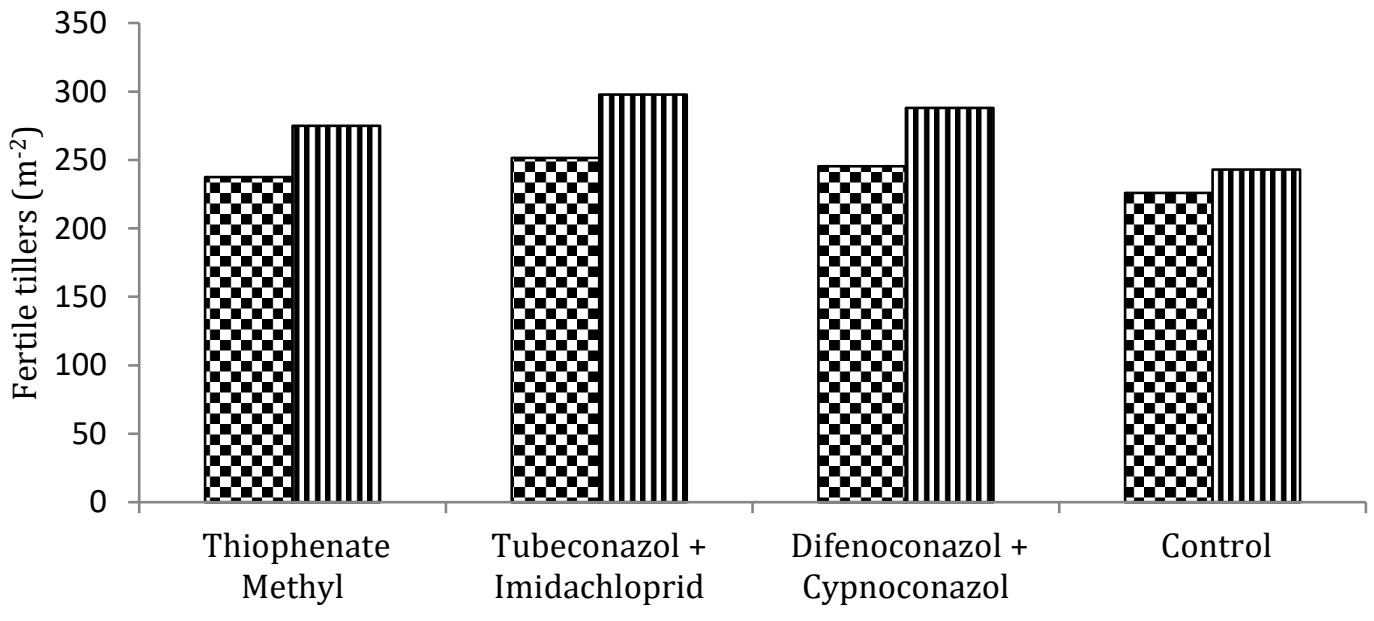

⑳15-16

[ 2016-17

Treamtents 
Effect of Seed dressing chemicals on grains per panicle of wheat

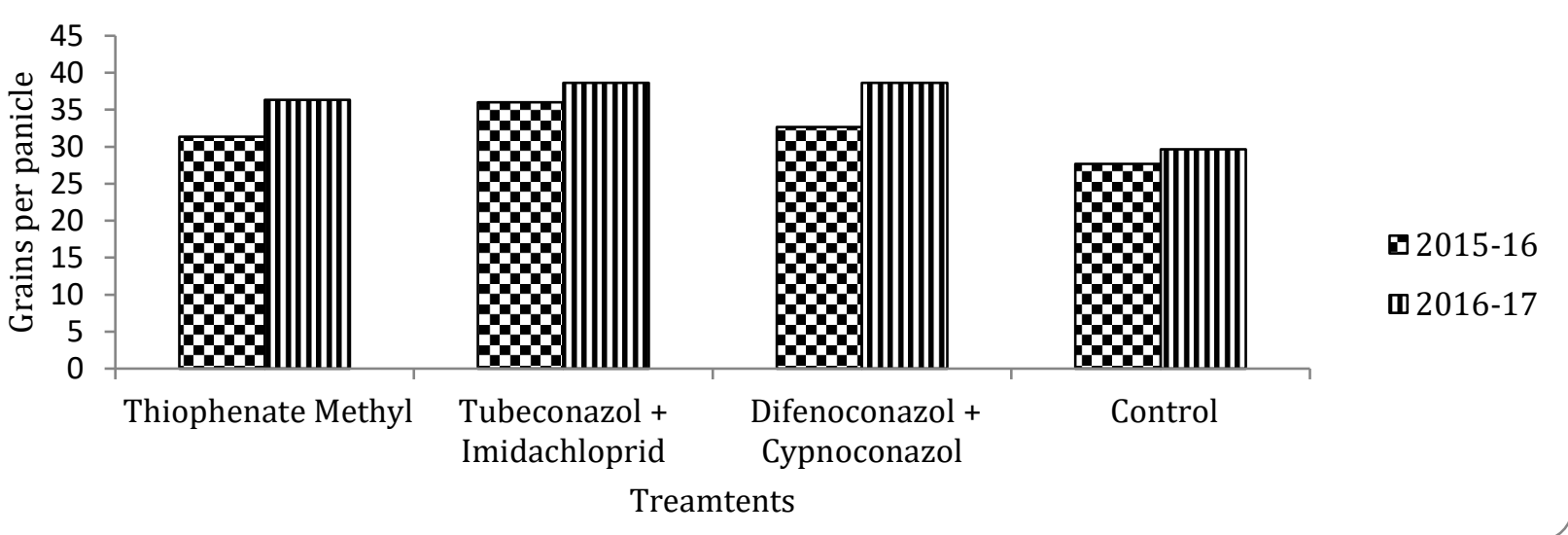

It is presented in (Table.2) that on the average of values obtained from two growing season about 9\% increase in plant heights, $17 \%$ more productive tillers per square meter, $31 \%$ increasing trend in healthy grains per spike \& $10 \%$ increase in thousand grains weight were recorded from the plot treated with $\mathrm{T}_{2}$ (Tubeconazol + Imidachloprid) as compared to untreated plot. Same trend of results offered by Bradley et al., (2001) and Cook et al., (2002) they reported that for disease management fungicidal treatment is commonly used and found positive impact of treating seeds with triazol fungicides on early plant growth. The findings of this study are also in agreement with those of Khanzada et al., (2002) tested the efficacy of different fungicides for the control of seed borne fungi and reported that all fungicides significantly increased the seedling emergence, grains per spike and thousand grains weight over control. Kadege., (2013) also reported that seed treatment with fungicides like metalaxyl plus mancozeb and others resulted in increasing trend of number of grain per spike, 100 grain weight and total grain yield.

Table 3. Effect of seed dressing fungicides on grain yield during two growing season.

\begin{tabular}{|c|c|c|c|c|c|}
\hline \multirow{3}{*}{\multicolumn{2}{|c|}{ Treatments }} & \multicolumn{4}{|c|}{ Grain Yield $\left(\mathrm{kg} \mathrm{ha}^{-1}\right)$} \\
\hline & & \multicolumn{2}{|c|}{ 2015-16 } & \multicolumn{2}{|c|}{$2016-17$} \\
\hline & & Yield & $\begin{array}{c}\% \text { increase } \\
\text { decrease }\end{array}$ & Yield & $\begin{array}{c}\text { \% increase/ } \\
\text { decrease }\end{array}$ \\
\hline \multicolumn{2}{|c|}{$\mathrm{T}_{1}=$ Thiophenate Methyl } & $3110.0 \mathrm{c}$ & 5.3 & $3513.3 \mathrm{~b}$ & 7.3 \\
\hline \multicolumn{2}{|c|}{$\mathrm{T}_{2}=$ Tubeconazol + Imidachloprid } & $3595.0 \mathrm{a}$ & 21.72 & $3713.3 \mathrm{a}$ & 13.4 \\
\hline \multicolumn{2}{|c|}{$\mathrm{T}_{3}=$ Difenoconazol + Cypnoconazol } & $3487.3 \mathrm{~b}$ & 18.0 & $3616.7 \mathrm{ab}$ & 10.5 \\
\hline \multicolumn{2}{|c|}{$\mathrm{T}_{4}=$ Control } & $2953.3 \mathrm{~d}$ & -- & $3273.3 \mathrm{c}$ & --- \\
\hline LSD P $\leq 0.05$ & & \multicolumn{2}{|c|}{151.18} & \multicolumn{2}{|c|}{117.21} \\
\hline \multicolumn{6}{|c|}{ Means having different letters differ significantly at $\mathrm{P} \leq 0.05$} \\
\hline \multirow[t]{2}{*}{ 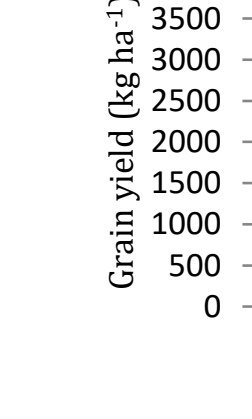 } & & 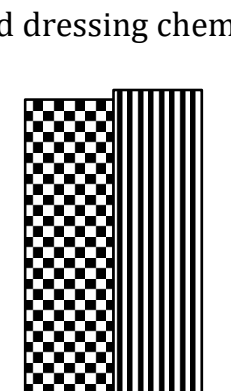 & 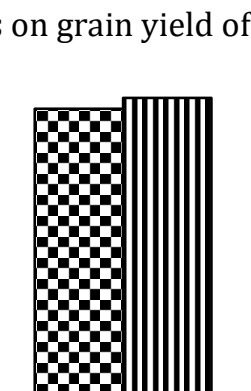 & $\mathbf{\beta} \mathbf{\alpha}$ & \multirow[t]{2}{*}{$\begin{array}{l}\text { 口2015-16 } \\
\text { ஐ2016-17 }\end{array}$} \\
\hline & Thiophenate Methyl & $\begin{array}{l}\text { Tubeconazol + } \\
\text { Imidachloprid }\end{array}$ & $\begin{array}{c}\text { Difenoconazol + } \\
\text { Cypnoconazol }\end{array}$ & Control & \\
\hline \multicolumn{6}{|c|}{ Treamtents } \\
\hline
\end{tabular}


Maximum grain yield $3654 \mathrm{~kg}$ per hectare was recorded from the plot treated with compound fungicide (tubeconazol + imidachloprid) on average of two growing seasons which is about 17.5 percent more than that of untreated plot (3113 kg per ha). Increase in grain yield in treated plots was due to increase in emergence percentage, productive tillers and healthy grains per spike. The results obtained, are in agreement with the findings of Malaker and Mian, (2009) who reported that seed treatment with fungicides improved plant population and increased grain yield. The results presented by Meisner et al., (1994) also supported our findings, they found that seed treatment with fungicides $23 \%$ increased the plant stand and grain yield by $18 \%$ under field condition.

Table 4. Impact of seed dressing fungicides on percent incidence of different diseases during two growing seasons.

\begin{tabular}{lcccccc}
\hline & \multicolumn{3}{c}{ Disease incidence percentage } & \multicolumn{2}{c}{ Disease incidence percentage } \\
dreatments & \multicolumn{3}{c}{ during 2015-16 } & during 2016-17 \\
\cline { 2 - 7 } & $\begin{array}{c}\text { Root } \\
\text { rot }\end{array}$ & $\begin{array}{c}\text { Loose } \\
\text { smut }\end{array}$ & $\begin{array}{c}\text { Black } \\
\text { point }\end{array}$ & $\begin{array}{c}\text { Root } \\
\text { rot }\end{array}$ & $\begin{array}{c}\text { Loose } \\
\text { smut }\end{array}$ & $\begin{array}{c}\text { Black } \\
\text { point }\end{array}$ \\
\hline $\mathrm{T}_{1}=$ thiophenate methyl & 13.3 & 1 & 3 & 20 & 2 & 4 \\
$\mathrm{~T}_{2}=$ tubeconazol + imidachloprid & 6.7 & 0 & 2 & 6.7 & 1 & 2 \\
$\mathrm{~T}_{3}=$ difenoconazol +cypnoconazol & 0 & 0 & 1 & 0 & 0 & 1 \\
$\mathrm{~T}_{4}=$ control (untreated) & 26.7 & 3 & 5 & 33.3 & 3 & 6 \\
\hline
\end{tabular}

Different trend regarding number of plants affected with root rot, loose smut and discloured grains was observed and presented in (Table4). Difenoconazol +cypnoconazol found the most effective compound fungicide as minimum or no incidence of disease was recorded while in the untreated plot $30 \%$ plants with rotted roots , $3 \%$ plants effected with loose smut and about $5.5 \%$ grains showed symptoms of black point disease during two growing season. It is clearly depicted from the results that wheat seeds treated with compound fungicides gave healthy plant stand and better grain yield. These findings are also in agreement with the results presented by several authors in different aspects studied at different locations. Siddiqui and Zaman, (2004) reported that seedborne fungi can be controlled by the seed treatment with fungicides. Chen et al., (2010) also reported that triazole fungicides as seed treatment protect the seedlings in the beginning of growing season. Similarly El-Kholy, (1999) also indicated that tebuconazole and triticonazole fungicides exhibited high fungicidal effects against the pathogens that cause root rot.

\section{CONCLUSION}

In punjab Pakistan mostly farmers used their own seed for next season wheat crop and it does not fulfil the standard of quality seed. This experiment brings out the efficacy of different fungicides as seed dressing in rice - wheat cropping system. The results of the study depict the benefits of fungicidal treatment to minimize the infection caused by seed or soil borne fungi that deteriorate the quality of seed. Tubeconazol + imidachloprid and Difenoconazol +cypnoconazol compound fungicides exhibited best results in increasng emergence percentage, plant stand \& vigour and reduce incidence of root rot, loose smut \& black point disease under ecological zone of Sheikhupura Punjab, Pakistan. However, the regular use of certain seed treatment fungicides capable of the eradicating the fungi in seed have also been extremely important.

\section{REFERENCES}

Anonymous. 2017. Agriculture Statistics of Pakistan. Ministry of Food, Agriculture and Livestock (MINFAL), Islamabad. Government of Pakistan, Economic Survey of Pakistan. 28.

Bailey, K. L. and G. Lazarovits. 2003. Suppressing soilborne diseases with residue management and organic amendments. Soil and Tillage Research, 72: $169-180$.

Bradley, C. A., L. M. Wax, S. A. Ebelhar, G. A. Bollero and W. L. Pedersen. 2001. The effect of fungicide seed protectants, seeding rates, and reduced rates of herbicides on no-till soybean. Crop Protection, 20: 615-622.

Briggs, K. and G. Dunn. 2000. Variation amongst Canadian six-row spring barley cultivars for germination and emergence characteristics in controlled environments and in the field. Canadian journal of plant science, 80: 247-253.

Chen, H.-G., Q.-G. Cao, G.-L. Xiong, W. Li, A.-X. Zhang, H.-S. $\mathrm{Yu}$ and J.-S. Wang. 2010. Composition of Wheat Rhizosphere Antagonistic Bacteria and Wheat Sharp Eyespot as Affected by Rice Straw Mulching. Pedosphere, 20: 505-514.

Cook, R. J., D. M. Weller, A. Y. El-Banna, D. Vakoch and H. Zhang. 2002. Yield Responses of Direct-Seeded Wheat to Rhizobacteria and Fungicide Seed Treatments. Plant Disease, 86: 780-784.

El-Kholy, R. M. A. 1999. Integrated control of some wheat 
diseaes. Fac. of Agric. (Cairo) Al-Azhar Univ., p. 229.

Galperin, M., S. Graf and D. Kenigsbuch. 2003. Seed treatment prevents vertical transmission of Fusarium moniliforme, making a significant contribution to disease control. Phytoparasitica, 31: 344-352.

Hasabnis, S., B. Ilhe and V. Shinde. 2006. Incidence of black point disease in wheat varieties. Journal Maharashtra Agriculture University, 31: 114.

Ilyas, M., S. Bokhari and M. Khan. 1998. Fungi detected from wheat seeds exhibiting black points symptoms and their control by seed treatment. Pakistan Journal of Phytopathology, 10: 86-89.

Kadege, E. L. 2013. Prevalence and control of seedborne fungal pathogens of wheat in farmers saved seeds of selected locations in Northern Tanzania. Sokoine University of Agriculture.

Khanzada, K. A., M. A. Rajput, G. S. Shah, A. M. Lodhi and F. Mehboob. 2002. Effect of Seed Dressing Fungicides for the Control of Seedborne Mycoflora of Wheat. Asian Journal of Plant Sciences, 1: 441444.

Krupinsky, J. M., K. L. Bailey, M. P. McMullen, B. D. Gossen and T. K. Turkington. 2002. Managing plant disease risk in diversified cropping systems. Agronomy Journal, 94: 198.

Majumdar. 1991. Crops of eastern Indian, West Bengal stage book board, Arg. Manson, (8th floor) 6/A, Raja Subodh malik squar Calcutta P.85.

Malaker, P. K. and I. H. Mian. 2009. Effect of seed treatment and foliar spray with fungicides in controlling black point disease of wheat. Bangladesh Journal of Agricultural Research, 34.

Matusinsky, P., R. Mikolasova, K. Klem and T. Spitzer. 2009. Eyespot infection risks on wheat with respect to climatic conditions and soil management. Journal of Plant Pathology: 93-101.

Munkvold, G. P. and J. K. O'Mara. 2002. Laboratory and Growth Chamber Evaluation of Fungicidal Seed Treatments for Maize Seedling Blight Caused by Fusarium Species. Plant Disease, 86: 143-150.
Paulitz, T. C. 2006. Low Input No-till Cereal Production in the Pacific Northwest of the U.S.: The Challenges of Root Diseases. European Journal of Plant Pathology, 115: 271-281.

Pikushova, E. A. 1995. Raxil (tubeconazol) on winter wheat zemled li No.3.38 (CF.RPP 1997 Vol.76 (10) p.1026 No.7915).

Platz, G. J., S.I. Meldrum and N. A. Webb. 2001. Chemical control of seed borne diseases of barley. Proceeding of the 10th Australian Barley Technical Symposium, Australia: Canberra, pp. 16-20.

Razzaque , M. A. and A. B. S. Hossain. 1991. The wheat development programme in Bangladesh " wheat for the non-traditional warm areas. Proceeding of International conference held in July 29 to Aug. 3, 1990. Fozdolguacu Brazil CIMMYT, pp. 44-54.

Rekanović, E., M. Mihajlović and I. Potočnik. 2010. In vitro sensitivity of Fusarium graminearum (Schwabe) to difenoconazole, prothioconazole and thiophanate-methyl. Pesticidi i fitomedicina, 25: 325-333.

Siddiqui, Z. Arif-uz-Zaman. 2004. Effects of benlate systemic fungicide on seed germination, seedling growth, biomass and phenolic contents in two cultivars of Zea mays L. Pakistan Journal of Botany, 36: 577-582.

Smiley, R. W., S. Machado, J. A. Gourlie, L. C. Pritchett, G. Yan and E. E. Jacobsen. 2013. Influence of Semiarid Cropping Systems on Root Diseases and Inoculum Density of Soilborne Pathogens. Plant Disease, 97: 547-555.

Solanki, V., N. Augustine and A. Patel. 2006. Impact of black point on wheat trade and its management. Indian Phytopathology, 59: 44.

Steel, R. G. D. and J. H. Torrie. 1980. Principles and procedures of statistics- a biometrical approach. McGraw Hill Book Co, New York.

Zishan, U., S.J.A. Shah and H. Shaukat. 2005. Studies on incidence of black point in different wheat cultivars grown in Pakistan. Sarhad Journal of Agriculture, 21(4): 723-728. 